Technical Note

\title{
A New Compendium of Soil Respiration Data for Africa
}

\section{Terence Epule Epule}

Département de Géographie, Université de Montreal, Pavillon 520, ch. de la Cote-Sainte-Catherine, Local 332-3 C.P 6128, succursale Centre-Ville, Montreal, QC H3C 3J7, Canada; E-Mail: terence.epule.epule@umontreal.ca; Tel.: +1-514-343-6111 (ext. 4960)

Academic Editor: Andreas Manz

Received: 12 January 2015 / Accepted: 22 April 2015 / Published: 27 April 2015

\begin{abstract}
The objective of this paper is to present to the scientific community a new dataset derived from existing literature on soil respiration in Africa. The data has thus been obtained by searching for records in peer review papers and grey literature. The main search engines used are: Scientific Citation Index (SCI) database, ISI Science web and Google scholar. This data description paper has greatly advanced the number of data points on soil respiration in Africa from 4 in 2010 to 62 in 2014. The new data points are culled from 47 peer review publications and grey literature reports. The data lends its self to a lot of possible analytical methods such as correlation analysis, multiple linear regressions, artificial neural network analysis and process base modeling. The overall conclusion that can be drawn here is that this paper has greatly advanced the availability of soil respiration data in Africa by presenting all the available records that before now were only reported in different studies.
\end{abstract}

Keywords: soil respiration; database; Africa

\section{Introduction}

Soil carbon is a vital component of the global carbon budget [1]. Due to its pertinent role in ecosystem carbon attenuation, soil respiration $\left(R_{S}\right)$ has become a valuable part of the global carbon cycle [2]. The concept of ecosystem carbon attenuation is used in this context to explain the fact that the higher the levels of carbon stored in soils without disturbance, the lesser the potential amounts of carbon emitted from the soil into other terrestrial ecosystems. Even though it has not been sufficiently documented and measured, it is the second largest terrestrial carbon flux [3,4]. Evidence of this is seen as about $8 \%-10 \%$ 
of atmospheric carbon dioxide originates from the soil. Globally, soils have a carbon pool that is twice as large as the atmospheric pool of carbon [5].

In Africa, inadequacies in $R_{S}$ data seem to be most pronounced when compared to other regions of the world. In 2010 most studies that had attempted to assemble data on $R_{S}$ had not been able to suggest more than four observations for the entire African continent. For example, Chen et al. [6], Bond-Lamberty and Thomson [7] published the most up to date global and regional databases of $R_{s}$ with only one [6] and four [7] data observation points respectively for Africa (Figure 1a). $R_{s}$ has been defined as the flux of carbon dioxide from soil surfaces to the atmosphere [7]. Though this current study used essentially the same methods as these earlier studies, minor differences (they did not include older papers that are not available from the web of science and grey literature) might account for the differences in the number of data points obtained on Africa.

As such, this study aims at verifying from existing literature, all possible studies with seasonal and annual data on $R_{S}$ in Africa. This data will be important to researchers because it will go a long way in providing data that will be used to verify critical questions. The availability of the data in itself does not answer any critical questions but provides an opportunity for researchers to use it and find answers to critical questions. Therefore, future studies that will make use of the data will respond to critical questions such as whether the surge in new data on $R_{S}$ significantly impacts the current climate debates through enhanced feedbacks. Such feedbacks will generally have repercussions on regional and global carbon cycles as well as on policies that will impact some of our current climate change adaptation strategies [8-12].

It is certain that thousands of $R_{S}$ observations have been collected globally over the decades yet, this effort itself has advanced very little or nothing on Africa. However, a regional database on $R_{S}$ in Africa will make available data that will not only impact the pace of research in this domain but will also affect existing climate change debates and ultimately enhance the predictability of existing global climate models [13-15]. The current shortage of adequate observations on $R_{S}$ based on Africa is indeed a mighty gap and this study is the first to establish a more comprehensive database on $R_{S}$ in Africa.

\section{Methods}

\subsection{Data Collection and Inclusion Criteria}

An elaborate literature survey of both peer review papers and grey literature that contain seasonal and annual measurements of $R_{S}$ was conducted. The studies included were either based on articles that covered $R_{S}$ research on a global scale and more specifically research that had been published on parts of Africa. We aimed at including studies published up to 2014. All laboratory incubation studies were left out. All the papers consulted were written in English or French and were obtained through the Scientific Citation Index (SCI) database, ISI Science web and Google scholar. All studies in other languages were excluded. The key search terminologies used were: soil respiration, global soil respiration, soil respiration studies in Africa, African soil $\mathrm{CO}_{2}$ evolution and flux. Once a paper was acquired, the title and abstract were used to verify if it could be of relevance to Africa. However, field measurements that were based on elevated $\mathrm{CO}_{2}$ experiments were excluded from this study. The data were either obtained from the text, tables and or figures. In the case of figures, estimates were obtained by reading the 
corresponding values from the figures using a software called Getdata Graph Digitizer version 2.26 (http://www.getdata-graph-digitizer.com/). In cases where more than one data point was presented for different ecosystem types for the same site, the two data points were included in the database based on the ecosystem types. This is the reason why in some cases the database has more than one measurement for different ecosystems in the same site. Most of the seasonal data included covered both the dry and the rainy season measurements and were made of two data points; in all cases where such seasonal data for both seasons were provided, the annual averages were calculated with $\pm 0.5 \mathrm{SD}$. The rest of the data were presented in this database exactly as they appear in the original text and only in cases in which seasonal data was provided that averages were calculated. For purposes of uniformity, the climate data associated to the various sites has been standardized [16]. Figure 1a,b was produced with the aid of Arc Map 10. This was achieved by uploading the data into the software and using the spatial distribution option to spatially represent the data on the maps. Basically, two main systems of soil nomenclatures have been used to classify the soil types presented in this study following the USDA and the FAO; these are the genetic and taxonomic nomenclatures. Firstly, the genetic classification considers climate as a major distinguishing factor. Here, the soils are classified as zonal soils and occur in the tropical humid climates; ferralitic soils belong to this category. Volcanic soils have also been classified under the genetic classification but differ because they are based on their poorly developed profile characteristics and could be presented as azonal soils. Finally, the taxonomic system of soil nomenclature is also vital. This is based on the soil textural characteristics and color. Most of the sandy soils, clay and loam soils belong to this group. Generally, for a paper to have been included in this study, it had to report at least one of the following:

-Mean/average seasonal soil respiration;

-Annual or mean annual soil respiration data;

-Q10 and related temperature variations;

$-\mathrm{R}_{10}$ with $R_{S}$ at $10^{\circ} \mathrm{C}$.

\subsection{Technical Validation}

Some basic quality control has been performed on the data. This is seen as maps have been used to make sure that the data plots referred to in the papers are in the correct locations. To verify cases of inaccuracy in the data, this paper has verified for cases where ecosystem respirations total is below $R_{S}$ and all such entries have been left out. Also, any data observations that are not in seasonal or annual format have been ignored. In cases where several observations are provided by the same study, duplication has been avoided as the specific latitudinal and longitudinal locations have been identified. However, whenever the same location coordinates have several observations, care has been taken to either discard the data if it is a duplicate or include it if it represents data for different ecosystems or soil types for the same site. The former being possible if we observe that several measurements were undertaken in the same transects. In cases where the temperature and rainfall data for a given region are not given, the location coordinates have been used to determine these variables. We have also employed Arc map analysis and "bird's eye view" techniques to present the data points on a map. This has been most useful in cases in which the actual location coordinates where the data was measured have not been 
given. Here, the "bird's eye view" technique helps in determining the location of the measurements by determining the general location of the sites on the map.

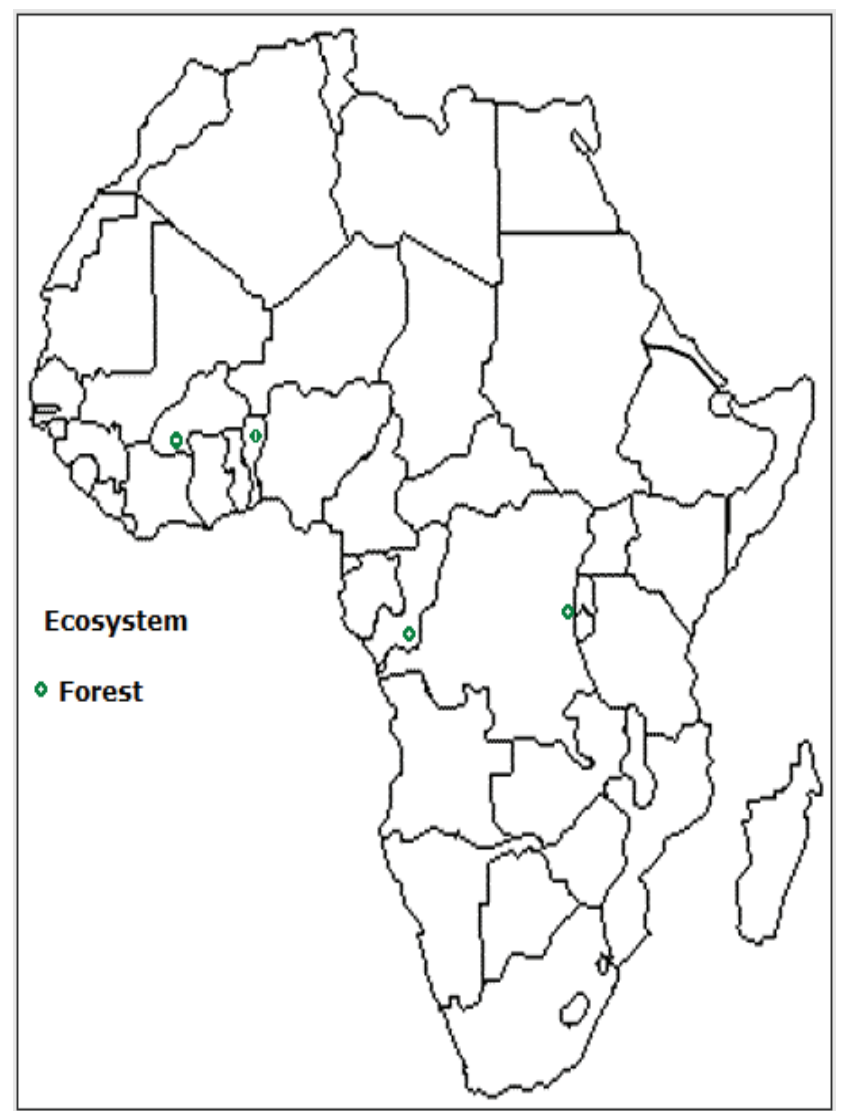

(a)

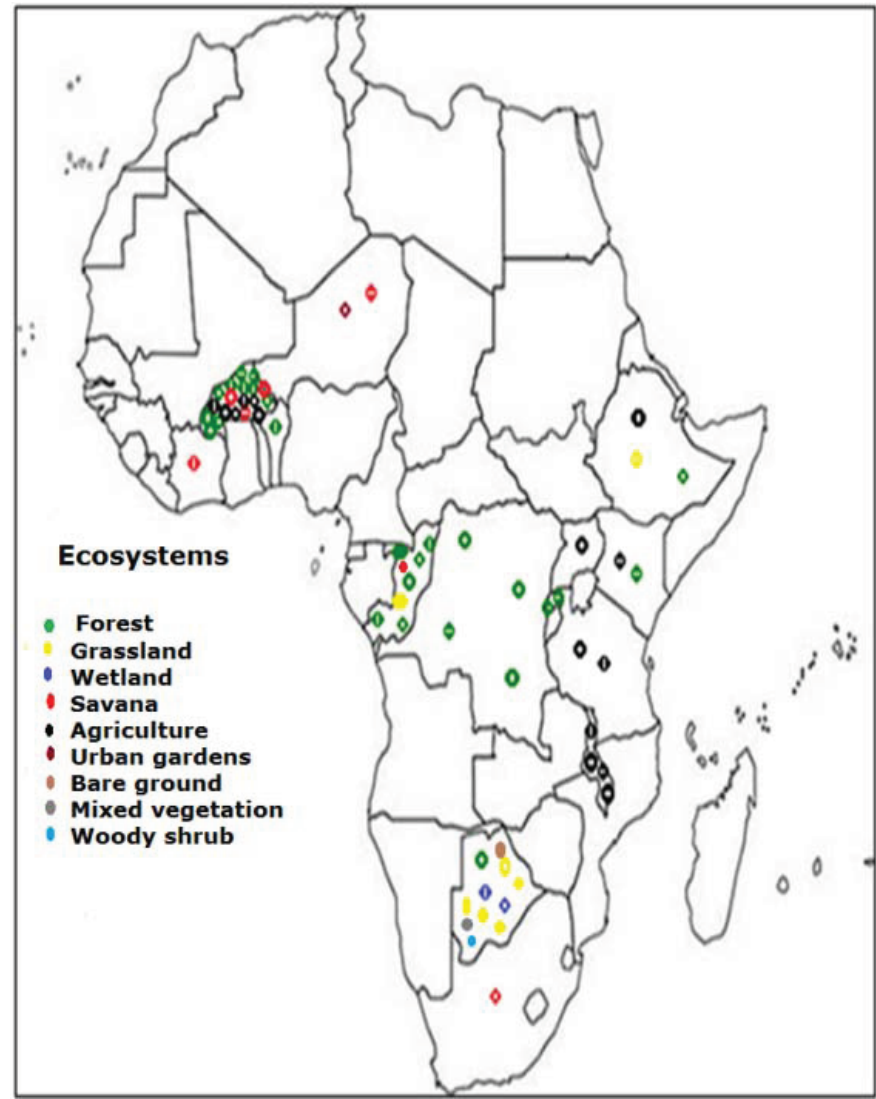

(b)

Figure 1. The evolution and spatial distribution of soil respiration observations for different African countries from (a) 4 observations in 2010 to (b) 62 observations in 2014 inspired by data collected for this study. The dots represent soil respiration measurements for different ecosystems and have been drawn using Arc Map 10 software.

\section{Results and Discussion}

Before this current study, previous studies [6,7] on $R_{S}$ in Africa have only presented 4 measurements (Figure 1a). This current study presents 62 published measurements of $R_{S}$ from 47 publications [1-47] (Figure 1b). Some of the publications reported multiple estimates or observations of $R_{S}$. The sites extended from Niger in the north $\left(13^{\circ} 32^{\prime} \mathrm{N}\right.$ and $\left.2^{\circ} 3^{\prime} \mathrm{E}\right)$ to South Africa in the south $\left(25^{\circ} 01^{\prime} \mathrm{S}\right.$ and $\left.31^{\circ} 23^{\prime} \mathrm{E}\right)$. From west to east we have Cote d'Ivoire $\left(6^{\circ} 13^{\prime} \mathrm{N}\right.$ and $\left.5^{\circ} 02^{\prime} \mathrm{W}\right)$ and Ethiopia $\left(7^{\circ} 06^{\prime} \mathrm{S}\right.$ and $\left.38^{\circ} 37^{\prime} \mathrm{E}\right)$.

In terms of major biomes, this database has mainly tropical and temperate biomes. However, the various ecosystems on which these observations have been carried out are more varied. Of the 62 observation acquired, 25 were on forest ecosystems, 15 on agricultural ecosystems, 7 on savannah ecosystems, 7 on grassland ecosystems, 2 on wetlands, 3 on mixed vegetation, 1 on bare ground, 1 on woody shrub and 1 on urban gardens [6-47] (Figure 2). Mixed vegetation refers to a situation in which several vegetation types co-exist in the same site, for example trees, grasses and shrubs co-existing together 
in mixed stands. Burkina Faso had the highest number of observations (19) [6-47] indicating that more $R_{S}$ research has been published.

In addition, this study has obtained the site names of the observations, their latitudinal and longitudinal locations, their elevations above sea level, the dominant biome type (which is either tropical or temperate), ecosystem type (which could be any of the following: forest, grassland, wetland, savannah, agriculture, mixed vegetation, bare ground and urban gardens). Ecosystem state is based on the level of natural or human interference in the ecosystem; in this case, this study has identified natural or undisturbed ecosystems and managed or disturbed ecosystems. Species refer to the various types of trees, shrubs and grasses found in the various study sites. The specific species identified are: Eucalyptus, Gilbertiodendron spp, Scorodophoeus spp, Brachystegia spp, Elaeis guineensis spp, Andropogon gayanus, Loudetiopsis kerstingii, C4 grass-Loudetia (Nees). Mixed species refer to scenarios in which several species listed already are found on the same site. Dry/arid species refer to those that thrive in harsh environments while wet species are those plants that are water tolerant. Leaf habit refers to the response of the vegetation to the various seasons; in this case this study has identified either plants that maintain their leaves all year round (evergreen) or those that shed their leaves during adverse seasons (deciduous). Stage is either described as aggrading, which refers to reductions in the productive capacity of the forest or mature, which refers to trees that have attained full productivity and harvest age.

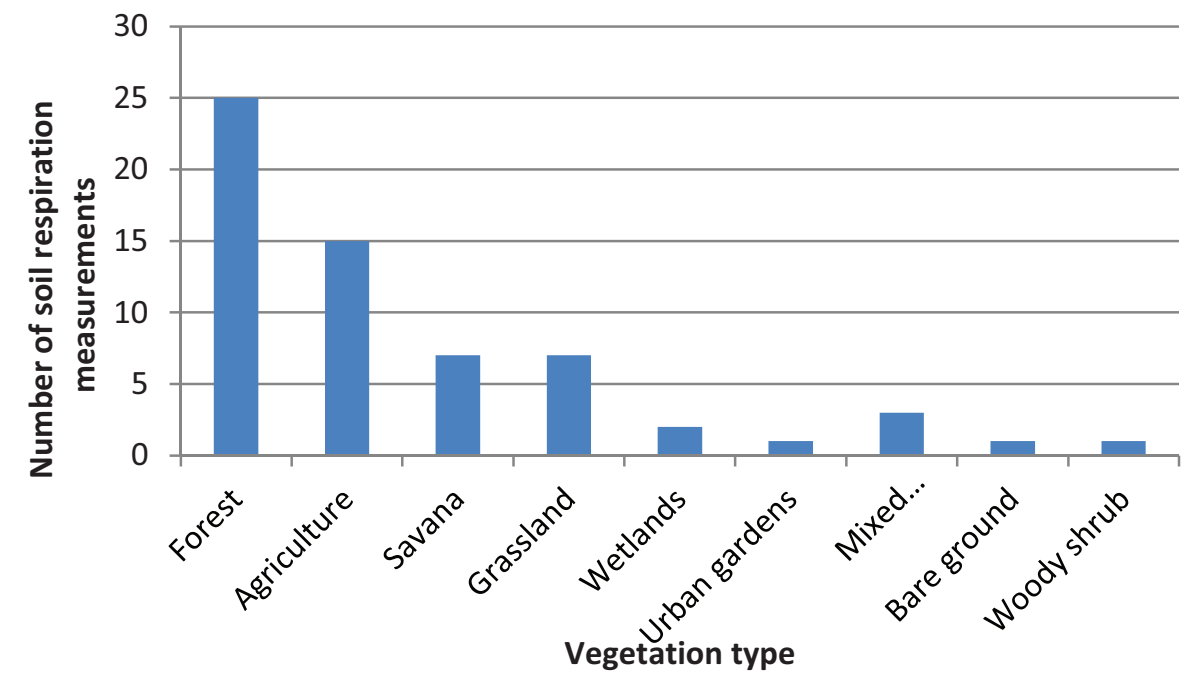

Figure 2. Main vegetation types and number of soil respiration measurements.

The principal soil types identified include arenosol, ferralitic, sandy soils, loam soils, granite, kandic rhodustaff, ustic quartz, clay-kanhaplic haplustults and volcanic soils; their main systems of classification has been presented above. Mean standardized annual precipitation and mean annual temperature were also computed [16]. However, in cases where ranges were given, the mean of the upper and lower range values was calculated. For studies that did not provide any temperature and rainfall information, we verified the missing rates from Hijmans [16]. The above procedure of calculating the mean values from ranges was used throughout the database where ranges were suggested by the consulted studies.

For future analysis, this study is suggesting that authors use correlation analysis, coefficient of determination, artificial neural networks, structural equation modeling and odd ratios inter alia to verify 
the degree of correlation between $R_{S}$ and variables such as rainfall and temperature as well as to map the distribution of $R_{S}$. Multiple linear regression and structural equation models could also be used to verify the impact of several variables on $R_{S}$ at the same time. This data is also usable in process based modeling. Authors are allowed to use this data in global and regional models to verify the effects of a surge in new data on previous models. However, caution has to be taken as the raw data will have to be converted into the same units to facilitate handling and manipulation. The data is presented in its original units for two reasons: (1) To provide users with the liberty of using it however they desire and (2) Due to strict instructions from our donors to have the data in its original form to preserve originality.

In the case of seasonal data, the annual means or averages have been calculated. This database has been uploaded on figshare. A digital object identifier (Doi) of doi:10.6084/m9.figshare.924740 [47] has been provided. Also, the database has been added to this current study as supplementary material. As such, with the freely available nature of this data in its original form, researchers have full access and can use it for various analyses as well as provide updates and corrections.

What do we gather from the 62 data points of $R_{S}$ presented in this study? The increase in the number of $R_{S}$ data points that this study has advanced shows that more studies on $R_{S}$ have been conducted in Africa. The rates of $R_{S}$ vary a lot within and among major vegetation biomes as can be seen on the dataset [6-46]. The lowest rates of $R_{S}$ occur in the coldest and driest biomes such as the tundra and northern bogs while the highest rates are recorded in the tropical moist forests where annual temperature and moisture are high all year round and where the standard error of the $R_{S}$ data is $>10 \%$ of the mean value. This goes a long way to show the coarse relationship between $R_{S}$ and vegetation type [46]. Generally, there are limited measurements of $\mathrm{CO}_{2}$ efflux from arid soils, natural savannas, woodlands, deciduous forests and deserts. In the midst of this, arid landscapes still cover close to one third of terrestrial land surface. This means that the shortage in measurements from such areas as revealed by the data presented in this study makes obvious a major deficiency in global $R_{S}$ estimation and simulation. So far, most $R_{S}$ studies are based on the temperate parts of the world at the detriment of the tropics that cover more than one third of the global landscape. This includes a rich plethora of diversified biomes with very high rates of $R_{S}$, yet not given adequate attention. Therefore, as seen by the database presented here, in spite of the abundance of global measurements of soil $R_{S}$, the global coverage is weak and this study is one effort at bringing the sparsely available data on Africa into a single source.

Based on the literature sources cited above, [6-46], the rates of $R_{S}$ in Africa are controlled by mean annual air temperatures and mean annual precipitation. Temperature for example is a great predictor of $R_{S}$ but adding precipitation increases the predictive capacity of most predictive models [46]. The variations in the rates of $R_{S}$ measurements have been observed for different vegetation types as seen in the data presented in this study [6-47]. In the literature, it is still unclear whether microbial decomposition rates (heterotrophic) are more responsible for the observed surges in $R_{S}$ than the activities of vascular plants (autotrophic).

\section{Conclusions}

This study has advanced the existing collection of $R_{S}$ measurements in Africa. At the end, 62 published estimates of $R_{S}$ were obtained from 47 publications; up from only 4 in 2010 . The implications of this improved dataset are that African soils still have a great potential of serving as major 
carbon stocks. Understanding the current trends in the flux of such soil carbon will go a long way to enhance our understanding of the rates of soil carbon flux into the atmosphere and consequently enhance the measures and options for better carbon sequestration and measurements. Before now, emphasis has been on the carbon stocks of flora at the expense of soils. Perhaps the lack of emphasis of previous research in this area is a weakness, but this study certainly describes the current state of research on $R S$ measurements in Africa.

\section{Acknowledgments}

Thanks go to the Fonds de Recherche du Québec-Société et Culture for funding this study through post doctoral grant number (2015-B3-180319). I am also grateful to 2 anonymous reviewers for their comments and suggestions.

\section{Conflicts of Interest}

The author declares no conflict of interest.

\section{References}

1. Schlesinger, W.H.; Andrews, J.A. Soil respiration and the global carbon cycle. Biogeochemistry 2000, 48, 7-20.

2. Ryan, M.G.; Law, B.E. Interpreting, measuring, and modeling soil respiration. Biogeochemistry 2005, 73, 3-27.

3. IPCC: Climate change 2001: The Science of Climate Change. Contribution of Working Group 1 to the Second Assessment Report of the Intergovernmental Panel on Climate Change, Cambridge University Press: Cambridge, UK, 2001.

4. Trumbore, S.E. Carbon respired by terrestrial ecosystems-recent progress and challenges. Glob. Change Biol. 2006, 12, 141-153.

5. Tarnocai, C.; Canadell, G.; Schuur, A.G.; Kuhry, P.; Mazhitova, G.; Zimov, S. Soil organic carbon pools in the northern circumpolar permafrost region. Glob. Biogeo. Cycles 2009, 23, doi:10.1029/2008GB003327.

6. Chen, S.; Huang, Y.; Zou, J.; Shen, Q.; Hu, Z.; Qin, Y.; Chen, H.; Pan, G. Modelling interannual variability of global soil respiration from climate and soil properties. Agri. For. Meteo. 2010, 150, 590-605.

7. Bond-Lamberty, B.; Thomson, A. A global database of soil respiration data. Biogeoscience 2010, 7 , 1915-1926.

8. Jones, C.D.; Cox, P.M.; Huntingford, C. Uncertainty in climate carbon cycle projections associated with sensitivity of soil respiration to temperature. Tellus B 2003, 55, 642-648.

9. Wise, M.; Calvin, K.; Thomson, A.; Clarke, L.; Bond-Lamberty, B.; Sands, R.; Smith, S.J.; Janetos, A.; Edmonds, J. Implications of limiting $\mathrm{CO}_{2}$ concentrations for land use and energy. Science 2009, 324, 1183-1186. 
10. Epron, D.; Nouvellon, Y.; Roupsard, O.; Mouvondy, W.; Mabiala, A.; Saint-Andre, L.; Joffre, R.; Jourdan, C.; Bonnefond, J.-M.; Berbigier, P.; et al. Spatial and temporal variations of soil respiration in a Eucalyptus plantation in Congo. For. Ecol. Manag. 2004, 202, 1021-1031.

11. Epron, D.; Nouvellon, Y.; Roupsard, O.; Mouvondy, W.; Mabiala, A.; Saint-Andre, L.; Joffre, R.; Jourdan, C.; Bonnefond, J.-M.; Berbigier, P.; et al. Soil carbon balance in a clonal Eucalyptus plantation in Congo: Effects of logging on carbon inputs and soil $\mathrm{CO}_{2}$ efflux. Glob. Change Biol. 2006, 12, 1021-1031.

12. Nouvellon, Y.; Nouvellon, Y.; Deleporte, P.; Ifo, S.; Kazotti, G.; M’bou, A.T.; Mouvondy, W.; Andre, L.S.; Roupsard, O.; Jourdan, C.; et al. Soil $\mathrm{CO}_{2}$ effluxes, soil carbon balance, and early tree growth following savannah afforestation in Congo: Comparison of two site preparation treatments. For. Ecol. Manag. 2008, 255, 1926-1936.

13. Davidson, E.A.; Janssens, I.A. Temperature sensitivity of soil carbon decomposition and feedbacks to climate change. Nature 2006, 1, 165-173.

14. Bond-Lamberty, B.; Thomson, A. Temperature-associated increases in global soil respiration record. Nature 2010, 464, 579-582.

15. Elberling, B.; Fensholt, R.; Larsen, L.; Petersen, A.-I.S.; Sandholt, I. Water content and land use history controlling soil $\mathrm{CO}_{2}$ respiration and carbon stock in savanna soil and groundnut fields in semi-arid Senegal. Danish J. Geog. 2003, 103, 47-56.

16. Hijmans, R.J.; Cameron, S.E.; Parra, J.L.; Jones, P.G.; Jarvis, A. Very high resolution interpolated climate surfaces for global land areas. Inter. J. Clim. 2005, 25, 1965-1978.

17. Caquet, B.; De Grandcourt, A.; M’bou, A.T.; Epron, D.; Kinana, A.; Andre, L.S.; Nouvellon, Y. Soil carbon balance in tropical grassland: Estimation of soil respiration and its partitioning using a semi-empirical model. Agri. For. Meteo. 2012, 158-159, 71-79.

18. Kim, D. Estimation of net gain of soil carbon in a nitrogen-fixing tree and crop intercropping system in sub-Saharan Africa: Results from re-examining a study. Agrofor. Sys. 2012, 86, 175-184.

19. Lamade, E.; Djegui, N.; Leterme, P. Estimation of carbon allocation to the roots from soil respiration measurements of oil palm. Plant Soil 1996, 181, 329-399.

20. Makumba, W.; Janssen, B.; Oenema, O.; Akinnifesi, F.K.; Mweta, D.; Kwesiga, F. The long-term effects of a gliricidia-maize intercropping system in Southern Malawi, on gliricidia and maize yields, and soil properties. Agri. Ecosys. Environ. 2006, 116, 85-92.

21. Mantlana, K.B.; Arneth, A.; Veenendaal, E.; Wohland, P.; Wolski, P.; Kolle, O. Seasonal and interannual soil $\mathrm{CO}_{2}$ efflux in savanna wetland mosaic in the Okavango Delta, Botswana. South Afr. J. Botany 2007, 73, doi:10.1016/j.sajb.2007.02.080.

22. Mordelet, P.; Abbadie, L.; Menaut, J.-C. Effects of tree clumps on soil characteristics in a humid savanna of West Africa (Lamto, Cote d'Ivoire). Plant Soil 1993, 153, 103-111.

23. Nsabimana, D.; Klemedtson, L.; Kaplin, B.A.; Wallin, G. Soil $\mathrm{CO}_{2}$ flux in six monospecific forest plantations in Southern Rwanda. Soil Biol. Biochem. 2009, 41, 239-402.

24. Predotova, M.; Gebauer, J.; Diogo, R.V.C.; Schlecht, E.; Buerkert, A. Emissions of ammonia, nitrous oxide and carbon dioxide from urban gardens in Niamey, Niger. Field Crops Res. 2010, $115,1-8$. 
25. Teklay, T.; Nordgren, A.; Malmer, A. Soil respiration characteristics of tropical soils from agriculture and forestry land-uses at Wondo Genet (Ethiopia) in response to $\mathrm{C}, \mathrm{N}$ and $\mathrm{P}$ amendments. Soil Biol. Biochem. 2006, 38, 125-133.

26. Verhoef A.; Allen, S.J.; De Bruin, H.A.R.; Jacobs, C.M.J.; Heusinkveld, B.G. Fluxes of carbon dioxide and water vapour from a Sahelian savanna. Agri. For. Meteo. 1996, 80, 231-248.

27. Yelemou, B.; Dayamba, S.D.; Bambara, D.; Yameogo, G.; Assimi, S. Soil carbon and nitrogen dynamics linked to Piliostigma species in ferugino-tropical soils in the Sudano-Sahelian zone of Burkina Faso. J. For. Res. 2013, 24, 99-108.

28. Brummer, C.; Papen, H.; Wassmann, R.; Bruggemann, N. Fluxes of $\mathrm{CH}_{4}$ and $\mathrm{CO}_{2}$ from soil and termite mounds in south Sudanian savanna of Burkina Faso (West Africa). Glob. Biogeoch. Cycles, 2007, 23, doi:10.1029/2008GB003237.

29. Gnankambary, Z.; IIstedt, U.; Nyberg, G.; Hien, V.; Malmer, A. Nitrogen and phosphorus limitation of soil microbial respiration in two tropical agroforestry parklands in the south-Sudanese zone of Burkina Faso: The effects of tree canopy and fertilization. Soil Biol. Biochem. 2008, 40, 350-359.

30. Koerber, G.R.; Edwards-Jones, G.; Nyeko, P.; York, E.H.; Jones, D.L. Geographical variation in carbon dioxide fluxes from soils in agro-ecosystems and its implications for life-cycle assessment. J. Appl. Ecol. 2009, 46, 306-314.

31. Makhado, R.; Scholes, R. Determinants of soil respiration in a semi-arid savanna ecosystem, Kruger National Park, South Africa. Afr. Prot. Area Con. Sci. 2011, 53, doi:10.4102/koedoe.v53i1.1041.

32. Makumba, W.; Akinnifesi, F.K.; Janssen, B.; Oenema, O. Long-term impact of a gliricida-maize intercropping system on carbon sequestration in southern Malawi. Agri. Ecosys. Environ. 2007, 118, 237-243.

33. Michelson, A.; Andersson, M.; Jensen, M.; Kjoller, A.; Gashew, M. Carbon stocks, soil respiration and microbial biomass in fire-prone tropical grassland, woodland and forest ecosystems. Soil Biol. Biochem. 2004, 36, 1707-1717.

34. Ngwira, A.; Sleutel, S.; De Neve, S. Soil carbon dynamics as influenced by tillage and crop residue management in loamy sand and sandy loam soils under smallholder farmers' conditions in Malawi. Nut. Cycl. Agroecosys. 2012, 92, 315-328.

35. Nsabimana, D.; Klemedtson, L.; Kaplin, B.; Wallin, G. Soil carbon and nutrient accumulation under forest plantations in southern Rwanda. Afr. J. Environ. Sci. Tech. 2008, 2, 142-149.

36. Nyberg, G.; Ekblad, A.; Buresh, R.J.; Hogberg, P. Respiration from $\mathrm{C}_{3}$ plant green manure added to a $\mathrm{C}_{4}$ plant carbon dominated soil. Plants Soils 2000, 218, 83-89.

37. Sugihara, S.; Funakawa, S.; Kilasara, M.; Kosaki, T. Effects of land management on $\mathrm{CO}_{2}$ flux and soil C stock in two Tanzanian croplands with contrasting soil texture. Soil Biol. Biochem 2012, 46, 1-9.

38. Traore, S.; Thiombiano, L.; Millogo, J.R.; Guinko, S. Carbon and nitrogen enhancement in Cambiosols and Vertisols by Acacia spp. In eastern Burkina Faso. Appl. Soil Ecol. 2007, 35, 660-669.

39. Wemer, C.; Kiese, R.; Butterbach-Bahl, K. Soil-atmosphere exchange of $\mathrm{N}_{2} \mathrm{O}, \mathrm{CH}_{4}$ and $\mathrm{CO}_{2}$ and controlling environmental factors for tropical rain forest sites in western Kenya. J. Geophys. Res. Atmos. 2007, 112, doi:10.1029/2006JD007388. 
40. Yohannes, Y.; Shibistova, O.; Abate, A.; Fetene, M.; Guggenberger, G. Soil $\mathrm{CO}_{2}$ efflux in an Afromontane forest of Ethiopia as driven by seasonality and tree species. For. Ecol. Manag. 2011, 261, 1090-1098.

41. Thomas, A.D. Impact of grazing intensity on seasonal variations in soil organic carbon and soil $\mathrm{CO}_{2}$ efflux in two semiarid grasslands in southern Botswana. Phil. Trans. Royal Soc. 2012, 2012, doi:10.1098/rstb.2012.0102.

42. Thomas, A.D.; Hoon, S.R.; Linton, P.E. Carbon dioxide fluxes from cyanobacteria crusted soils in the Kalahari. Appl. Soil Ecol. 2008, 39, 254-263.

43. Thomas, A.D.; Dougill, A.J.; Elliott, D.R.; Mairs, H. Seasonal differences in soil $\mathrm{CO}_{2}$ efflux and carbon storage in Ntwetwe Pan, Makgadikgadi basin, Botswana. Geoderma 2014, 219-220, 72-81.

44. Castaldi, S.; de Grandcourt, A.; Rasile, A.; Skiba, U.; Valentini, R. Fluxes of $\mathrm{CO}_{2}, \mathrm{CH}_{4}$ and $\mathrm{N}_{2} \mathrm{O}$ from soil of buried grassland of central Africa. Biogeoscience 2010, 7, 3459-3471.

45. Thomas, A.D.; Hoon, S.R.; Dougill, A.J. Soil respiration at five sites along the Kalahari Transect: Effects of temperature, precipitation pulses and biological soil crust cover. Geoderma 2010, 167-168, 284-294.

46. Raich, J.W.; Schlesinger, W.H. The global carbon dioxide flux in soil respiration and its relationship to vegetation and climate. Tellus $B$ 1992, 44, 81-99.

47. Epule, T.E.; A new compendium of soil respiration data for Africa. Figshare 2014, 2014, doi:10.6084/m9.figshare.924740.

(C) 2015 by the authors; licensee MDPI, Basel, Switzerland. This article is an open access article distributed under the terms and conditions of the Creative Commons Attribution license (http://creativecommons.org/licenses/by/4.0/). 